\title{
Comparative Analysis of Efficiency Measurement of Banks in the Turkish Banking System
}

\author{
Asst. Prof. Dr. Ebru Esendemirli (Yaşar University, Turkey) \\ Asst. Prof. Dr. Emine Yasemin Yeğinboy (Dokuz Eylül University, Turkey)
}

\begin{abstract}
The global developments at the beginning of 21 st century raised different issues about the banking sector. International banks are being effective since 2001 in emerging markets while U.S. banking sector is dealing with the consequences of the crisis in 2008. Furthermore the flow of funds from developed countries to emerging markets had an increasing trend due to the globalization of the capital markets. Banks have a major role in Turkish financial system. The aim of this study is to measure and compare the efficiency of banks in Turkish banking industry. The first part of the study reports a descriptive summary about the general appearance of the Turkish banking system. The second part of the study discusses the theoretical aspects in measuring the efficiency of banks. In the third part of the study, a non-parametric method, data envelopment analysis is used to analyze the efficiency of foreign banks, private banks and participation banks. As a result the average efficiency score of foreign banks in 2008-2012 is slightly higher than the average efficiency of participation banks. Although there isn't a very large difference, foreign banks and participation banks are more efficient than private banks.
\end{abstract}

\section{Introduction}

In the last decade both emerging markets and developed countries were exposed to financial crisis. For instance in countries like Turkey and United States supporting financial liberalization with incompetent regulation and supervision provided the ground for crisis. Banking sector one of the key players of financial markets is going through a rapid change due to the global effects of crisis. In February 2001 a banking crisis broke out in Turkish economy due to structural problems like unsustainable amount of internal debt stock, high inflation rate, fragilities in Turkish banking sector and ambiguities in political environment. As a result 22 banks were transferred to Savings Deposit Insurance Fund (SDIF) with a restructuring cost of USD 53.6 billion (BRSA, 2010). After the crisis structural reforms were put into action to maintain economic and financial stability. The financial reforms covered; (i) solving the financial problems of banks under SDIF control, (ii) restructuring the state owned banks, (iii) strengthening the capital of private banks through mergers and share transfers and (iv) adopting legislative measures (BAT, 2009b). Following the crisis and the financial reforms, the total assets rose from USD 130 billion to nearly USD 800 billion during the period of 2002-2014 (BRSA, 2014c).

United States was exposed to financial crisis started in December 2007 due to massive growth, increased complexity and leverage in credit securities and credit derivatives (FSA, 2009). Risky mortgages worth trillions of dollars were circulated throughout the financial system while mortgage related derivatives were traded around the world. Dramatic failures in accountability, transparency, ethics, corporate governance, risk management, credit rating mechanisms combined with poor financial regulation and supervision caused excessive borrowing and risky investments resulting in a global financial crisis (FCIC, 2011). The immediate effect of the crisis was the collapse of a globally known two institutions; an investment bank Lehman Brothers and an insurance company American International Group (AIG). The impact of the crisis was felt by households and business in U.S and in all around the world. The cost of crisis is assumed to be an output loss of USD 6 trillion to USD 14 trillion which amounts to a loss of between USD 50,000 to USD 120.000 for every U.S. household (Lutterall et al., 2013).

The purpose of this study is to measure the efficiency trend of different bank groups in Turkish banking sector after the local and global crisis occurred in 2001 and 2008. The contribution of this paper for scholars and practitioners is that it provides an efficiency analysis of banks for post-crisis period. The research is an initial in analyzing and comparing the efficiency of participation banks with other bank groups. Data is gathered for the period of 2008-2012 and examined using the method of data envelopment analysis (DEA) model.

\section{General Appearance of Turkish Banking Sector}

In Turkey financial system is operating with small scales and at the growth stage when compared with developed countries (BAT, 2009b). Banking sector has a leading role in terms of asset size, number of employees, branches, transactions and customers (BRSA, 2013) The growing trend of banking sector is continuing in the recent years. Due to the developments in information and communication technologies the volume of financial transactions provided by internet banking and mobile banking has increased. The number of ATM and POS machines has expanded due to the 
Table 2.1 presents the number of banks in Turkish banking sector according to the ownership structure of different bank groups. The three functional groups in Turkish banking sector are; deposit banks, development \& investment banks and participation banks according to the Banking Law No. 5411. There are totally 49 banks by September 2013. The structural reforms after 2001 crisis required improvements in the capital adequacy levels in banking sector. Therefore banks strengthened capital through mergers and share transfers. 16 mergers and acquisitions occurred during the period of 2001 - 2011 (BRSA, 2010). As a result there are 17 foreign deposit banks. Foreign shares in private deposit banks are \%20,5 whereas foreign shares in participation banks are $\% 54$. The total foreign contribution in terms of the weighted paid-in capital shares is approximately $\% 30$.

The organic growth of Turkish banking sector is continuing despite the local banking crisis in 2002 and global financial crisis in 2008. Thus the growth of selected indicators for the period of $2002-2102$ is presented in Table 2. For instance in 2012 the assets have increased by 5.8 times reaching to an amount of TL 1.237 billion. Loans were the main item in speedy asset growth which has increased by 15 times, from TL 49 billion to TL 737 billion. The increase in loans is evidence that banks are performing intermediary activities. There is a significant growth in the amount of off-balance sheet items due to expanding rate of derivative transactions and revocable unused credit lines in recent years. Even though the loss from capital market transactions and growth of operational expenses had a negative effect, the income creation capacity of the sector has increased in 2012.

\begin{tabular}{|l|c|c|c|c|}
\hline \multirow{2}{*}{ Bank Group } & \multirow{2}{*}{ Number } & \multicolumn{3}{c|}{ Ownership Structure (\%) } \\
\cline { 3 - 5 } & 32 & Trading in BIST & Other Resident & Other Non-Resident \\
\hline Deposit Banks & 3 & 19,8 & 42,7 & 37,4 \\
\hline State-Owned & 12 & 19,9 & 80,1 & 0,0 \\
\hline Private & 17 & 29,5 & 50,0 & 20,5 \\
\hline Foreign & 1 & 0,1 & 1,9 & 98 \\
\hline SDIF & 13 & 0 & 100 & 0 \\
\hline Development \& Investment Banks & 4 & 4 & 93,3 & 2,7 \\
\hline Participation Banks & 19 & 27 & 54 \\
\hline
\end{tabular}

Table 1: Ownership Structure (In terms of paid-in capital, as of September 2013, perc.) Source: BAT, $2013 \mathrm{~b} \&$ $T K B B, 2013$

\begin{tabular}{|l|c|c|c|c|c|c|c|c|}
\hline TL Billion & $\mathbf{2 0 0 2}$ & $\mathbf{2 0 0 4}$ & $\mathbf{2 0 0 6}$ & $\mathbf{2 0 0 8}$ & $\mathbf{2 0 0 9}$ & $\mathbf{2 0 1 0}$ & $\mathbf{2 0 1 1}$ & Jun 2012 \\
\hline Loans & 49 & 99,3 & 219,0 & 367,4 & 392,6 & 525,9 & 682,9 & 737,2 \\
\hline Deposits & 132 & 191,1 & 307,6 & 454,6 & 514,6 & 617,0 & 695,5 & 718,8 \\
\hline Total Assets & 212,7 & 306,4 & 499,7 & 732,5 & 834 & $1.000,7$ & $1.217,7$ & $1.237,7$ \\
\hline Off-Bal. Sheet & 154,6 & 277,4 & 476,0 & 579,8 & $1.038,1$ & $1.664,3$ & $1.709,4$ & $1.767,9$ \\
\hline Total Int. Income & 44,4 & 40,3 & 55,8 & 85,8 & 85,3 & 77,4 & 39,9 & 54,8 \\
\hline Total Int. Expense & 31,6 & 22,7 & 34,6 & 54,8 & 43,5 & 38,7 & 21,8 & 30,2 \\
\hline Net Profit & 2,9 & 6,5 & 11,4 & 13,4 & 20,2 & 22,1 & 10,4 & 11,6 \\
\hline
\end{tabular}

Table 2: Selected Indicators for Turkish Banking Sector 2002 - 2012 Source: BRSA, 2012

\begin{tabular}{|l|c|c|c|c|c|c|c|}
\hline TL Million & $\begin{array}{c}\text { State- } \\
\text { Owned } \\
\text { Banks }\end{array}$ & $\begin{array}{c}\text { Private } \\
\text { Banks }\end{array}$ & Foreign Banks & $\begin{array}{c}\text { Participation } \\
\text { Banks }\end{array}$ & $\begin{array}{c}\text { Investment \& } \\
\text { Development } \\
\text { Banks }\end{array}$ & $\begin{array}{c}\text { SDIF } \\
\text { Bank }\end{array}$ & $\begin{array}{c}\text { Banking } \\
\text { Sector } \\
\text { Total }\end{array}$ \\
\hline $\begin{array}{l}\text { Number of } \\
\text { Employees }\end{array}$ & 54.466 & 94.747 & 42.746 & 16.800 & 5.244 & 260 & 214.810 \\
\hline $\begin{array}{l}\text { Number of } \\
\text { Branches }\end{array}$ & 3.397 & 5.411 & 2.171 & 965 & 40 & 2 & 11.986 \\
\hline TotalAssets & 483.378 & 842.002 & 239.948 & 96.086 & 70.137 & 869 & 1.732 .420 \\
\hline Loans & 277.040 & 518.913 & 143.819 & 62.042 & 45.614 & 1 & 1.047 .428 \\
\hline Deposits & 300.536 & 456.834 & 127.068 & 61.313 & - & 19,7 & 945.770 \\
\hline Own Funds & 45.204 & 95.060 & 25.097 & 8.851 & 18.938 & 658 & 193.807 \\
\hline CAR & 13,5 & 14,8 & 15,5 & 14,0 & 32,7 & 38,4 & 15,3 \\
\hline $\begin{array}{l}\text { Net Period } \\
\text { Profit }\end{array}$ & 7.741 & 13.288 & 1.456 & 1.071 & 1.171 & - & 24.733 \\
\hline ROA & 1,8 & 1,7 & 0,7 & 1,3 & 1,9 & - & 1,6 \\
\hline ROE & 19,8 & 15,4 & 6,4 & 14,0 & 6,6 & - & 14,2 \\
\hline
\end{tabular}

Table 3: Selected Indicators for Different Bank Groups in Turkish Banking Sector for December 2013 Source: BRSA, 2013

As illustrated in Table 3, net period profit of banking sector has reached to TL 24 billion by the end of 2013. There are 49 banks operating with 11,986 branches and 214,810 employees in Turkish banking sector. Private 
banks have a leading role in a number of items such as number of employees, number of branches, total assets, loans, deposits, own funds and net period profit. State-owned banks have the highest ROE with 19,8 while foreign banks have the highest capital adequacy ratio (CAR) which is 15,5.

Deposit banks have a significant dominance in Turkish banking sector while a decrease in the asset size and number of branches is observed during the period of $2002-2103$. As presented in Table 4 the asset size of participation banks has increased by $\% 130$ and the growth rate for number of branches is $\% 321$ since 2002 . The loan size and number of branches for development and investment banks have a declining trend whereas the mentioned banks have the highest return on asset ratio in the sector.

\begin{tabular}{|c|c|c|c|c|c|c|c|}
\hline$\%$ & 2002 & 2004 & 2006 & 2008 & 2009 & 2010 & 2013 \\
\hline \multicolumn{8}{|l|}{ Total Asset Size (\%) } \\
\hline Deposit Banks & 94,4 & 94,2 & 93,9 & 93,4 & 92,7 & 92,6 & 90,5 \\
\hline Dev.\&Inv. Banks & 3,2 & 3,2 & 3,1 & 3,1 & 3,2 & 3,1 & 4 \\
\hline Participation Banks & 2,4 & 2,6 & 3,1 & 3,5 & 4,0 & 4,3 & 5,5 \\
\hline Total & 100 & 100 & 100 & 100 & 100 & 100 & 100 \\
\hline \multicolumn{8}{|l|}{ Loans $(\%)$} \\
\hline Deposit Banks & 87,6 & 90,2 & 92,5 & 92 & 90,5 & 91,1 & 89,7 \\
\hline Dev.\&Inv. Banks & 8,3 & 5,1 & 3,3 & 3,2 & 3,5 & 3,0 & 4,4 \\
\hline Participation Banks & 4,1 & 4,7 & 4,3 & 4,8 & 6,0 & 5,9 & 5,9 \\
\hline Total & 100 & 100 & 100 & 100 & 100 & 100 & 100 \\
\hline \multicolumn{8}{|c|}{ Number of Branches $(\%)$} \\
\hline Deposit Banks & 97,6 & 95,6 & 94,5 & 93,8 & 93,6 & 93,6 & 91,7 \\
\hline Dev.\&Inv. Banks & 0,6 & 0,5 & 0,6 & 0,5 & 0,5 & 0,4 & 0,3 \\
\hline Participation Banks & 1,9 & 3,9 & 4,9 & 5,8 & 5,9 & 6,0 & 8,0 \\
\hline Total & 100 & 100 & 100 & 100 & 100 & 100 & 100 \\
\hline \multicolumn{8}{|l|}{ ROA / ROE } \\
\hline Deposit Banks & $1,2 / 10,7$ & $2,1 / 15,0$ & $2,2 / 20,3$ & $1,7 / 16,4$ & $2,4 / 19,7$ & $2,2 / 17,8$ & $1,53 / 14,92$ \\
\hline Dev.\&Inv. Banks & $4,9 / 15,5$ & $2,8 / 6,1$ & $4,8 / 9,7$ & $4,0 / 8,7$ & $3,7 / 7,8$ & $2,7 / 6,0$ & $1,9 / 6,6$ \\
\hline Participation Banks & $0,4 / 4,4$ & $1,4 / 10,7$ & $2,8 / 25,1$ & $2,5 / 17,4$ & $2,1 / 16,0$ & $1,8 / 13,9$ & $1,3 / 14,0$ \\
\hline
\end{tabular}

Table 4: Market Share and Profitability Analysis of Bank Groups in Turkish Banking Sector 2002 - 2013 Source: BRSA, 2010

\section{Efficiency Measurements in Banking Sector}

A significant amount of research explored efficiency of banks in Turkey and in other countries. The most used technique for efficiency analysis in studies identifying banking efficiency is Data Envelopment Analysis (DEA), originally proposed by Farrell (1957). Since then a number of papers extended and applied DEA methodology. For instance Charnes, Cooper, Rhodes (1978) developed a model which had an input oriented constant returns to scale (CRS) and Banker, Charnes, Cooper (1984) proposed variable returns to scale (VRS) model (Coelli, 1996). In light of the developments about DEA methodology it has been widely used in studies about efficiency measurements in banking sector.

Behdioglu and Ozcan (2009) concluded that foreign banks were the most efficient groups in Turkey during 1999-2005 in their study using DEA application. A different result was assessed by Kok and Ay (2013) about the period of 2007-2009. They observed that state-owned banks were the most efficient group with DEA. Celik and Kaplan (2010) investigated efficiency and competition relationship while Seyrek and Ata (2010) predicted financial performance indicators using efficiency scores of banks in Turkey. Similarly Halkos and Salamouris (2004) proposes that DEA can be used as an alternative or complement to ratio analysis in their study measuring the performance of the Greek banking sector.

Staub et. al. examined cost, technical and allocative efficiencies for Brazilian banks using Data DEA for the period of 2000-2007. The results indicate that Brazilian banks have low levels of economic efficiency when compared with banks operating in Europe and U.S. Athanassopoulos and Giokas (2000) applied DEA approach in their case study, for measuring performance, productive and market efficiency of branches in the Commercial Bank of Greece.

A brief summary of the inputs and outputs proposed by past studies is presented in Table 5. Accordingly interest expenses, non-interest expenses, number of branches, number of employees, total deposits are the frequently used input parameters while interest income, total loans and net profit are the commonly used output parameters by scholars. The previous studies cover efficiency measurements in either pre-crisis or the crisis period of 2007-2008. The aim of this study is to fill the gap for post-crisis period in efficiency measurements of banking sector. 


\begin{tabular}{|l|l|c|l|l|}
\hline Year & Author(s) & Period of Analysis & Inputs & Outputs \\
\hline 2004 & Halkos \& Salamouris & $1997-1999$ & $\begin{array}{l}\text { Interest Expenses } \\
\text { Total Assets } \\
\text { Number of Employees } \\
\text { Operating Expenses }\end{array}$ & $\begin{array}{l}\text { Interest Income } \\
\text { Net Profit }\end{array}$ \\
\hline 2009 & Behidoglu \& Ozcan & $1999-2005$ & $\begin{array}{l}\text { Number of Employees } \\
\text { Non-Interest Expenses } \\
\text { Interest Expenses } \\
\text { Number of Branches }\end{array}$ & $\begin{array}{l}\text { Total Deposits } \\
\text { Total Loans } \\
\text { Net Profit }\end{array}$ \\
\hline 2010 & Seyrek \& Ata & $2003-2008$ & $\begin{array}{l}\text { Total Deposits } \\
\text { Interest Expenses } \\
\text { Non-Interest Expenses }\end{array}$ & $\begin{array}{l}\text { Total Loans } \\
\text { Interest Income } \\
\text { Non-Interest } \\
\text { Income }\end{array}$ \\
\hline 2013 & Kok \& Ay & & $\begin{array}{l}\text { Number of Employees } \\
\text { Number of Branches } \\
\text { Total Loans } \\
\text { Toterest Expenses }\end{array}$ & Total Assets \\
\hline
\end{tabular}

Table 5: Inputs and Outputs Proposed by Past Studies in Efficiency Measurements of Banks

\section{Methodology and Data}

The aim of the study is to measure the comparative effectiveness of different bank groups operating in Turkey after the global financial crises occurred in 2008. In this respect data from three bank groups; private banks, foreign banks and participation banks is collected for the period of 2008-2012. Investment and development banks are not included in the analysis because they don't collect deposits. The research is an initial in analyzing and comparing the efficiency of participation banks with other bank groups. Because there are four participation banks operating with either medium or small scales, four banks with similar scales are chosen for private and foreign bank groups using. Banks with asset size shares more than 5\% in the sector are classified as large scale, between $1 \%-5 \%$ are medium scale and between $0,20 \%$ and $1 \%$ are small scale banks. Large scale banks are not included in the study.

Data issued annually in "Banks in Turkey" by BAT (2009a, 2010, 2011, 2012, 2013a) and statistical reports disclosed by Turkish Participation Banks Association (TKBB, 2013) in the website is used for the selection and information gathering process. For instance, in this part, comparative information about the selected indicators of the analyzed banks is presented. Changes in paid-in capital, number of branches and employees for the analyzed banks are reported in Table 6. Accordingly, increases are observed for paid-in capital, number of branches and employees of private and participation banks during 2008-2012. Paid-in capital is constant for foreign banks

\begin{tabular}{|c|c|c|c|c|c|c|c|c|c|c|c|c|c|}
\hline & Banks & \multicolumn{3}{|c|}{$\begin{array}{l}\text { Paid-in Capital } \\
\text { (TL Million) }\end{array}$} & \multicolumn{3}{|c|}{$\begin{array}{l}\text { Number of } \\
\text { Branches }\end{array}$} & \multicolumn{3}{|c|}{ Number of Employees } & \multicolumn{3}{|c|}{$\begin{array}{c}\text { Number of } \\
\text { Employees Per } \\
\text { Branch }\end{array}$} \\
\hline & Years & $\stackrel{\infty}{\stackrel{\Upsilon}{\circ}}$ & $\frac{1}{8}$ & $\%$ & 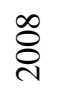 & $\frac{1}{\overparen{N}}$ & $\%$ & $\stackrel{\infty}{\stackrel{\Upsilon}{\circ}}$ & 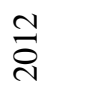 & $\%$ & ণ্ঠి & $\frac{\mathrm{N}}{\mathrm{D}}$ & $\%$ \\
\hline \multirow{4}{*}{ 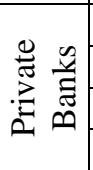 } & Şekerbank & 400 & 1.000 & 150 & 250 & 272 & 8,8 & 4.089 & 3.565 & 12,8 & 16 & 13 & $(18,5)$ \\
\hline & TEB & 1.100 & 2.204 & 100 & 336 & 509 & 51,5 & 6.400 & 9.288 & 45,1 & 19 & 18 & $(5,2)$ \\
\hline & Anadolubank & 410 & 600 & 47,5 & 77 & 91 & 18,2 & 1.718 & 2.024 & 17,8 & 22 & 22 & 0 \\
\hline & Alternatifbank & 300 & 420 & 40 & 46 & 63 & 37 & 1.006 & 1.230 & 22,2 & 21 & 19 & $(9,5)$ \\
\hline \multirow{4}{*}{ 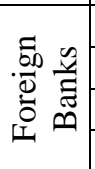 } & ING Bank & 1.324 & 2.786 & 110 & 366 & 319 & $(12,8)$ & 6.357 & 5.319 & $(19,1)$ & 17 & 16 & $(5,8)$ \\
\hline & Citibank & 34 & 34 & 0 & 56 & 37 & $(33,9)$ & 2.315 & 2.123 & $(8,29)$ & 41 & 57 & 39,0 \\
\hline & Denizbank & 716 & 716 & 0 & 400 & 610 & 52,5 & 7.376 & 10.280 & 39,3 & 18 & 16 & $(11,1)$ \\
\hline & HSBC Bank & 652 & 652 & 0 & 335 & 338 & 0,089 & 6.853 & 6.170 & 9,9 & 20 & 18 & $(10)$ \\
\hline \multirow{4}{*}{ 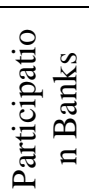 } & AlbarakaTürk & 269,5 & 900 & 234 & 100 & 137 & 37 & 1.799 & 2.758 & 53,3 & 17 & 20 & 17,6 \\
\hline & Asya Finans & 900 & 900 & 0 & 149 & 251 & 68,5 & 3.806 & 5.064 & 33,1 & 15 & 20 & 33,3 \\
\hline & Kuveyt Türk & 500 & 1.100 & 120 & 113 & 221 & 95,6 & 2.246 & 3.939 & 75,3 & 19 & 17 & $(10.5)$ \\
\hline & TürkiyeFinans & 800 & 1.650 & 106 & 174 & 220 & 26,4 & 3.185 & 3.595 & 12,8 & 18 & 16 & $(11,1)$ \\
\hline
\end{tabular}

Table 6: Changes in Paid-in Capital, Number of Branches and Employees for the Analyzed Banks Source: BAT; 2009a, 2012; TKBB, 2013 
Changes in selected balance sheet items for banks under analysis are disclosed in Table 7. In this respect, a significant growth in total assets, total loans and deposits of all bank groups is observed while participation banks have the highest rate. There are negative changes in net profit of period for some of the foreign and participation banks whereas the profitability trend is upwards for all private banks.

\begin{tabular}{|c|c|c|c|c|c|c|c|c|c|c|c|c|c|}
\hline \multirow{2}{*}{\multicolumn{2}{|c|}{$\begin{array}{c} \\
\text { Banks } \\
\text { Years }\end{array}$}} & \multicolumn{3}{|c|}{$\begin{array}{l}\text { Total Assets } \\
\text { (TL Million) }\end{array}$} & \multicolumn{3}{|c|}{$\begin{array}{c}\text { Total Loans, } \\
\text { Receivables and } \\
\text { Funds Allocated (TL } \\
\text { Million) }\end{array}$} & \multicolumn{3}{|c|}{$\begin{array}{l}\text { Total Deposit and } \\
\text { Funds Collected } \\
\text { (TL Million) }\end{array}$} & \multicolumn{3}{|c|}{$\begin{array}{l}\text { Net Profit of } \\
\text { Period } \\
\text { (TL Million) }\end{array}$} \\
\hline & & 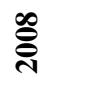 & ำ & $\%$ & 官 & ำ & $\%$ & ڤ్ & ิㅗำ & $\%$ & 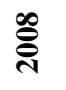 & ำ & $\%$ \\
\hline \multirow{4}{*}{ 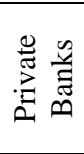 } & Şekerbank & 8.041 & 14.518 & 80,5 & 4.800 & 9.974 & 107 & 6.508 & 10.887 & 67,2 & 144 & 240 & 66,6 \\
\hline & TEB & 14.736 & 43.532 & 195 & 8.505 & 29.686 & 249 & 11.717 & 33.906 & 189 & 164 & 486 & 196 \\
\hline & Anadolubank & 3.384 & 6.291 & 85,9 & 1.958 & 4.176 & 113 & 2.529 & 4.148 & 64 & 87 & 166 & 90,8 \\
\hline & Alternatifbank & 3.745 & 7.969 & 112 & 2.371 & 5.201 & 119 & 3.187 & 5.203 & 63 & 53 & 68 & 28,3 \\
\hline \multirow{4}{*}{ 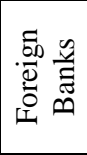 } & ING Bank & 16.503 & 25.115 & 52,1 & 11.044 & 18.842 & 70,6 & 12.898 & 20.366 & 57 & 140 & 252 & 80 \\
\hline & Citibank & 5.451 & 7.420 & 36,1 & 2.513 & 2.678 & 65,6 & 4.274 & 6.158 & 44 & 81 & 89 & 9,8 \\
\hline & Denizbank & 19.225 & 44.198 & 129 & 12.759 & 28.191 & 120,1 & 14.579 & 25.464 & 74 & 278 & 813 & 192 \\
\hline & HSBC Bank & 14.696 & 25.299 & 72,1 & 9.724 & 15.422 & 58,5 & 11.554 & 19.903 & 72 & 250 & 181 & $(27,6)$ \\
\hline \multirow{4}{*}{ 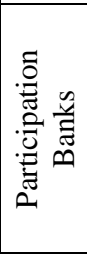 } & $\begin{array}{l}\text { Albaraka } \\
\text { Türk } \\
\end{array}$ & 4.789 & 12.327 & 157 & 3.616 & 10.270 & 184 & 3.985 & 10.562 & 165 & 136 & 191 & 40,4 \\
\hline & Asya Finans & 8.108 & 21.390 & 163 & 8.153 & 15.803 & 93,8 & 6.299 & 15.667 & 148 & 246 & 190 & $(22,7)$ \\
\hline & Kuveyt Türk & 5.768 & 18.910 & 227 & 4.134 & 11.664 & 182 & 4.869 & 15.667 & 221 & 104 & 250 & 140 \\
\hline & $\begin{array}{l}\text { Türkiye } \\
\text { Finans } \\
\end{array}$ & 7.104 & 17.616 & 147 & 5.393 & 12.666 & 134 & 5.573 & 12.012 & 115 & 160 & 283 & 76,8 \\
\hline
\end{tabular}

Table 7: Changes in Selected Balance Sheet Items for Analyzed Banks Source: BAT; 2009a, 2012; TKBB, 2013

Table 8 reports changes in selected income statement items for analyzed banks. For instance, in all bank groups the growth rate of interest / profit share income is greater than the growth of interest / profit share expenses. Profit share income and profit share expenses are the terminology used in income statement of participation banks. Even though, all banks have net profits in 2008 and 2012, some of them have a declining trend in profit growth. To illustrate, net operating profits for Alternatifbank, HSBC Bank and Asya Finans have decreased in 2012 when compared with 2008.

\begin{tabular}{|c|c|c|c|c|c|c|c|c|c|c|}
\hline & \multirow{2}{*}{$\begin{array}{l}\text { Banks } \\
\text { Years }\end{array}$} & \multicolumn{3}{|c|}{$\begin{array}{l}\text { Interest / Profit Share } \\
\text { Income (TL Million) }\end{array}$} & \multicolumn{3}{|c|}{$\begin{array}{l}\text { Interest / Profit Share } \\
\text { Expenses (TL Million) }\end{array}$} & \multicolumn{3}{|c|}{$\begin{array}{l}\text { Net Operating Profit } \\
\text { (TL Million) }\end{array}$} \\
\hline & & 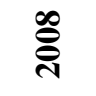 & 줄 & $\%$ & 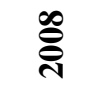 & 공 & $\%$ & $\stackrel{\infty}{\stackrel{\overbrace{}}{ి}}$ & ָับ & $\%$ \\
\hline \multirow{4}{*}{ 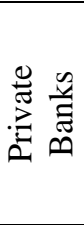 } & Şekerbank & 1.322 & 1.731 & 30,9 & 695 & 896 & 28,9 & 182 & 311 & 70,8 \\
\hline & TEB & 1.966 & 3.938 & 100 & 1.262 & 2.094 & 65,9 & 197 & 641 & 225 \\
\hline & Anadolubank & 473 & 759 & 60,4 & 258 & 349 & 35,2 & 109 & 211 & 93,5 \\
\hline & $\begin{array}{l}\text { Alternatifban } \\
\mathrm{k}\end{array}$ & 449 & 857 & 90,8 & 252 & 440 & 74,6 & 67 & 42 & $(37,3)$ \\
\hline \multirow{4}{*}{ 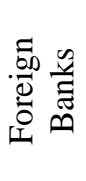 } & ING Bank & 2.209 & 2.403 & 8,7 & 1.400 & 1.058 & $(24,4)$ & 185 & 353 & 90,8 \\
\hline & Citibank & 757 & 732 & $(3,3)$ & 336 & 276 & $(17,8)$ & 102 & 113 & 107 \\
\hline & Denizbank & 2.363 & 4.095 & 73 & 1.528 & 3.071 & 100 & 328 & 993 & 202 \\
\hline & HSBC Bank & 2.235 & 2.473 & 106 & 1.063 & 1.130 & 6,3 & 306 & 240 & $(21,5)$ \\
\hline \multirow{4}{*}{ 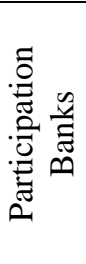 } & $\begin{array}{l}\text { Albaraka } \\
\text { Türk }\end{array}$ & 534 & 965 & 80,7 & 295 & 509 & 72,5 & 171 & 293 & 71,3 \\
\hline & Asya Finans & 963 & 1.586 & 64,6 & 1.109 & 787 & $(29,0)$ & 311 & 245 & $(21,2)$ \\
\hline & Kuveyt Türk & 523 & 1.296 & 147 & 298 & 584 & 95,9 & 263 & 309 & 17,4 \\
\hline & $\begin{array}{l}\text { Türkiye } \\
\text { Finans }\end{array}$ & 710 & 1.350 & 90,1 & 423 & 617 & 45,8 & 202 & 293 & 45,0 \\
\hline
\end{tabular}

Table 8: Changes in Selected Income Statement Items for Analyzed Banks Source: BAT; 2009a, 2012; TKBB, 2013

To measure and compare the efficiency of banks in different bank groups, a non-parametric method, Data Envelopment Analysis is used. Data Envelopment Analysis Program developed by Coelli (1996) is applied under the assumption of constant returns to scale (CRS). Data Envelopment Analysis is a non-parametric method. 
Input-oriented technical efficiency measurement is used. Due to the intermediary function of deposit and participation banks, funds borrowed, interest/profit share expenses, deposits are used as inputs while interest/profit share income, loans, net operating profit are used as outputs.

\section{Results}

The results of the input oriented CRS model for analyzed banks are presented in Table 9. Accordingly, foreign banks have the highest average efficiency score of 0,9918 for the period of $2008-2012$. HSBC, with an efficiency score 1, is the most efficient Bank in the group. Foreign banks are closely followed by participation banks which have an average efficiency score of 0,9878. Türkiye Finans is the most efficient bank in the group with a score of 1 . Private deposit banks have the lowest average efficiency score which is 0,9504 .

\begin{tabular}{|c|c|c|c|c|c|c|c|}
\hline & Years & 2008 & 2009 & 2010 & 2011 & 2012 & Average \\
\hline \multirow{5}{*}{ 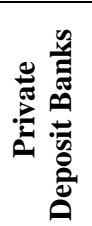 } & Şekerbank & 1 & 1 & 0,8791 & 1 & 0,9052 & 0,9568 \\
\hline & $\begin{array}{l}\text { Türk Ekonomi } \\
\text { Bankası }\end{array}$ & 0,8711 & 0,8698 & 0,8121 & 0,9450 & 0,8598 & 0,8716 \\
\hline & Anadolubank & 1 & 1 & 1 & 1 & 1 & 1 \\
\hline & Alternatifbank & 0,8919 & 0,9766 & 1 & 1 & 1 & $\mathbf{0 , 9 7 3 7}$ \\
\hline & Average & 0,9403 & 0,9616 & 0,9228 & 0,9862 & 0,9412 & 0,9504 \\
\hline \multirow{5}{*}{ 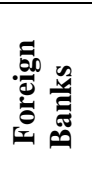 } & ING Bank & 0,9530 & 1 & 1 & 1 & 1 & 0,9906 \\
\hline & Citibank & 1 & 0,9714 & 1 & 1 & 1 & 0,9942 \\
\hline & Denizbank & 1 & 1 & 1 & 0,9156 & 1 & 0,9831 \\
\hline & HSBC Bank & 1 & 1 & 1 & 1 & 0,9958 & 0,9991 \\
\hline & Average & 0,9882 & 0,9928 & 1 & 0,9789 & 0,9989 & 0,9918 \\
\hline \multirow{5}{*}{ 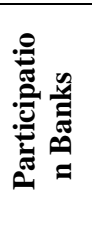 } & Albaraka Türk & 1 & 1 & 0,9189 & 1 & 1 & $\mathbf{0 , 9 8 3 7}$ \\
\hline & $\begin{array}{l}\text { Asya Finans } \\
\text { Kurumu }\end{array}$ & 1 & 1 & 0,9127 & 1 & 1 & 0,9825 \\
\hline & Kuveyt Türk & 1 & 1 & 1 & 0,9260 & 1 & 0,9852 \\
\hline & Türkiye Finans & 1 & 1 & 1 & 1 & 1 & 1 \\
\hline & Average & 1 & 1 & 0,9579 & 0,9815 & 1 & $\mathbf{0 , 9 8 7 8}$ \\
\hline
\end{tabular}

Table 9: Efficiency Scores of the Analyzed Banks

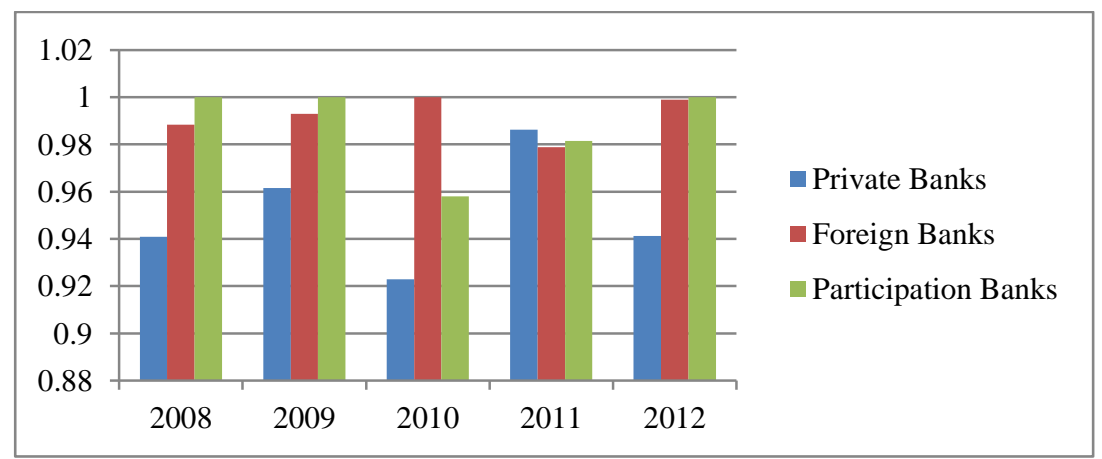

Figure 1: Comparative Analysis for Efficiency Scores of Bank Groups in 2008-2012

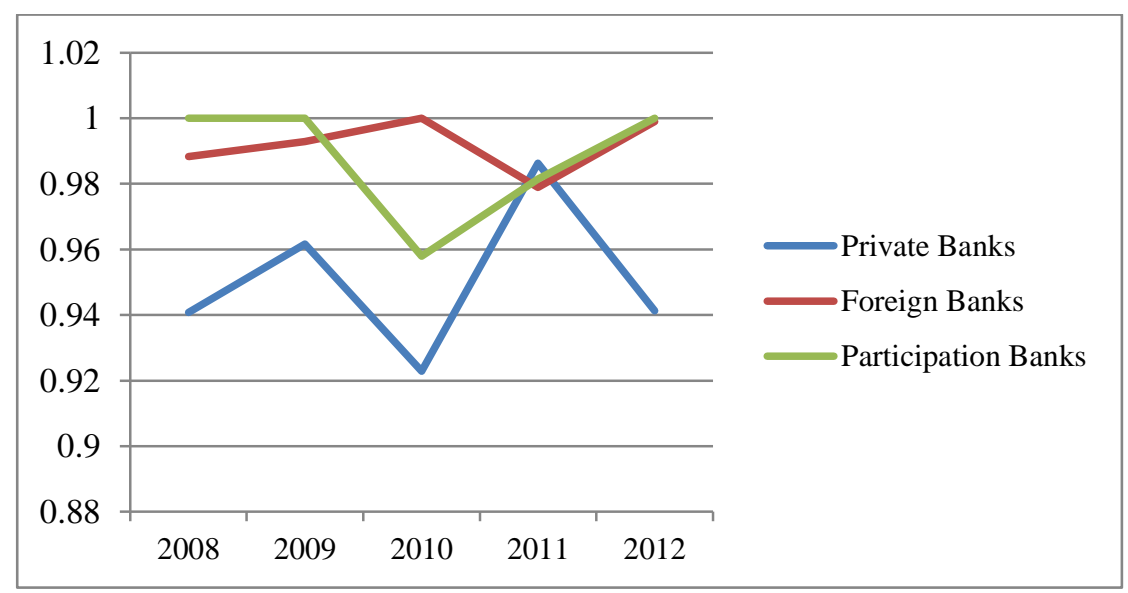

Figure 2: Trend Analysis for Efficiency Scores of Bank Groups in 2008-2012 
Comparative analysis for efficiency scores of bank groups are presented in Figure 1. In 2008 and 2009 participation banks were fully efficient and they were followed by foreign banks. In 2010, foreign banks were the most efficient while private banks had the lowest average efficiency scores among the other groups. 2011 was the only year when the private banks were the most efficient. In 2012 the efficiency scores of participation and foreign banks were very close where participation banks were slightly ahead. Private banks' success in 2011 didn't continue in 2012. Yet, they had the lowest efficiency scores.

Figure 2 illustrates the trend analysis for efficiency scores of bank groups during the period of 2008 and 2012. In 2008, 2009 and 2012 participation banks have the highest efficiency score of 1. In 2010 foreign banks and in 2011 private banks have the highest efficiency scores. The overall performance of foreign banks is the highest while participation banks have an increasing trend in efficiency scores since 2010. In 2011 and 2012 participation banks are little far efficient than foreign banks. Private banks had unsteady efficiency scores in five years. Even though they recovered from 2010 and performed an efficient year in 2011, the improvement didn't continue in 2012. Foreign banks and participation banks had an upward trend of efficiency scores whereas private banks had a downward trend of efficiency scores in 2012. However the difference is not very large. In fact the average efficiency scores of the three bank groups for the period of 2008-2012 are close to each other.

\section{Conclusion}

The growing trend of Turkish banking sector is continuing in the recent years despite the local banking crisis in 2001 and global financial crisis in 2008. Total assets rose from USD 130 billion to nearly USD 800 billion during the period of 2001-2013. Foreign banks and participation banks had increased their effectiveness since 2001 in the banking system. This paper examined the comparative efficiency of private banks, foreign banks and participation banks during the post-global crisis period of 2008-2012. Because there are four banks with medium and small scales operating in participation banks group, four banks with similar scales are chosen from foreign and private banks groups. Data Envelopment Analysis, a non-parametric method frequently applied by scholars measuring bank performance, is used for efficiency evaluation. The inputs of the efficiency model are funds borrowed, interest/profit expenses, deposits and the outputs are interest/profit share income, loans, net operating profit. The results show that average efficiency score of foreign banks is the highest for the mentioned 5 year period. Participation banks' average efficiency score is very close to performance of foreign banks. Further, in 2008, 2009 and 2012 participation banks were fully efficient. The findings of the study are consistent with the evaluation of BRSA in the report about Structural Developments in Banking (2010): “...Numeric data show that the participation banks are presenting a performance above the sector for all capacity indicators and that they are in a fast development process." This study is an initial in comparing the performance of participation banks with other bank groups. In addition, the efficiency performance of private banks is lower than the efficiency performance of foreign banks and participation banks.

\section{References}

- Athanassopoulos, A. D., Giokas D., 2000. "The Use of Data Envelopment Analysis in Banking Institutions: Evidence from the "Commercial Bank of Greece" Interfaces, Vol. 30, No. 2, pp. 81-95

- BAT - The Banks Association of Turkey, 2009a. "Banks in Turkey 2008". http://www.tbb.org.tr/en/Content /Upload/Dokuman/44/Turkish_Banking_System_2008.pdf

- BAT - The Banks Association of Turkey, 2009b. "The Financial System and Banking Sector in Turkey" http://www.tbb.org.tr/en/Content/Upload/Dokuman/38/The_Financial_System_and_Banking_Sector_in _Turkey.pdf

- BAT - The Banks Association of Turkey, 2010. "Banks in Turkey 2009" http://www.tbb.org.tr/en/Content/ Upload/Dokuman/43/2Bankalarimiz2009ING.pdf.

- BAT - The Banks Association of Turkey, 2011. "Banks in Turkey 2010” http://www.tbb.org.tr/en/Content/ Upload/Dokuman/42/Bankalarimiz2010ingesas.pdf

- BAT - The Banks Association of Turkey, 2012. "Banks in Turkey 2011” http://www.tbb.org.tr/en/Content/ Upload/Dokuman/41/Banks2011.pdf

- BAT - The Banks Association of Turkey, 2013a. "Banks in Turkey 2012" http://www.tbb.org.tr/en/Content/ Upload/Dokuman/126/Bankalarimiz_kompING-basim.pdf

- BAT - The Banks Association of Turkey, 2013b. “The Banking Sector in Turkey 2009 - 2013” http://www.tbb.org.tr/en/Content/Upload/Dokuman/127/The_Banking_Sector_in_Turkey_2009-2013_ December.pdf

- Banker, R. D., Charnes, A., Cooper, W. W, 1984. "Some Models for Estimating Technical and Scale Inefficiencies in Data Envelopment Analysis", Management science, 30(9), pp. 1078-1092 
- Behdioglu, S., Ozcan, G., 2009. "Data Envelopment Analysis and an Application in Banking Sector", Süleyman Demirel University, Journal of Faculty of Economics and Administrative Sciences, Vol.14, No.3, pp.301-326

- $\quad$ Ben S. Bernanke, 2009. "Financial Regulation and Supervision after the Crisis: The Role of the Federal Reserve" At the Federal Reserve Bank of Boston 54th Economic Conference, Chatham, Massachusetts, http://www.federalreserve.gov/newsevents/speech/bernanke20091023a.htm

- BRSA - Banking Regulation and Supervision Agency, 2010. "Structural Developments in Banking”, http://www.bddk.org.tr/WebSitesi/english/Reports/Structural_Developments/10132byg5_eng_final_230911. pdf

- BRSA - Banking Regulation and Supervision Agency, 2012. "Financial Markets Report" http://www.bddk.org.tr/WebSitesi/english/Reports/Financial_Markets_Report/11588financial_markets_repor t_june_2012.pdf

- BRSA - Banking Regulation and Supervision Agency, 2013. "Turkish Financial System: The Review of 2012 and Trends" https://www.bddk.org.tr/WebSitesi/english/Reports/Financial_Markets_ Report/11899fmr_dec2012_eng_0504131700.pdf

- BRSA - Banking Regulation and Supervision Agency, 2014a. "Türk Bankacılık Sektörü Genel Görünümü” http://www.bddk.org.tr/WebSitesi/turkce/Raporlar/TBSGG/12779tbs_genel_gorunumu_aralik_2013.pdf

- $\quad$ BRSA - Banking Regulation and Supervision Agency, 2014b. http://www.bddk.org.tr/WebSitesi/turkce/Kuruluslar/Bankalar/Bankalar.aspx

- BRSA - Banking Regulation and Supervision Agency, 2014c. http://ebulten.bddk.org.tr/ABMVC/en\#.

- Charnes, A., Cooper, W. W., Rhodes, E., 1978. "Measuring the Efficiency of Decision Making Units", European Journal of Operational Research, 2(6), pp. 429-444.

- Celik, T., Kaplan, M., 2010. "Efficiency and Competition in Turkish Banking Sector: 2007-2009”, Sosyoekonomi, Vol.6, Issue 2, pp 7-28

- Coelli, T. A. 1996. "Guide to DEAP, Version 2.1: A Data Envelopment Analysis (Computer) Program”, Center for Efficiency and Productivity Analysis. University of New England. Working paper, 96(08) pp1-50

- Farrell, M. J., 1957. “The Measurement of Productive Efficiency”, Journal of Royal Statistical Society, 120(3), pp. 253-290

- FSA - Financial Services Authority, 2009. "The Turner Review A Regulatory Response” http://www.fsa.gov.uk/pubs/other/turner_review.pdf

- FCIC - The Financial Crisis Inquiry Commission, 2011. "The Financial Crisis Inquiry Report" http://www.gpo.gov/fdsys/pkg/GPO-FCIC/pdf/GPO-FCIC.pdf

- Halkos, G. E., \& Salamouris, D. S. 2004. "Efficiency measurement of the Greek commercial banks with the use of financial ratios: a data envelopment analysis approach.” Management Accounting Research, 15(2), 201-224

- $\quad$ Kok, D., Ay, O. E, 2013. “A Research on the Reflection of 2008 Global Financial Crisis on the Efficiency Level of Turkish Banking Sector in the Period of 2007-2009”, International Journal of Economic and Administrative Sciences, Vol.5 No.10, pp.155-170

- $\quad$ Lutterell, D., Atkinson, T., Rosenblum, H., 2013. “Assessing the Costs and Consequences of 2007-2009 Financial Crisis and Its Aftermath" DallasFed Economic Letter Vol. 8, No. 7 http://www.dallasfed.org/assets/documents/research/eclett/2013/el1307.pdf

- $\quad$ Seyrek İ.H., Ata H.A, 2010. "Efficiency Measurement in Deposit Banks Using Data Envelopment Analysis and Data Mining”, BRSA, Journal of Banking and Financial Markets, Vol. 4, Issue 2, pp. 67-84.

- $\quad$ TKBB - Turkish Participation Banks Association, 2012. "Participation Banks in The Financial System of Turkey" http://tkbb.org.tr/general-presentation.aspx?pageID=178

- $\quad$ TKBB - Turkish Participation Banks Association, 2013. Statistical Reports, http://tkbb.org.tr/auditingreports-of-member-banks.aspx?pageID=192 